\title{
Generation Mean Analysis for Yield and its Components in Blackgram [Vigna mungo (L.) Hepper]
}

\author{
G. D. Vadodariya*, D. A. Chauhan, R. K. Patel, K. G. Modha, \\ Y. V. Naghera and S. K. Jadav
}

Dept. of genetics and Plant Breeding, N M College of Agriculture, Navsari Agricultural University, Navsari - 369 450, India

*Corresponding author

\begin{tabular}{|c|c|}
\hline & A B S T R A C T \\
\hline & Generation mean analysis was carried out by in two cross NUK-15-02 $\times$ NUK-15-07 and \\
\hline $\begin{array}{l}\text { Ke y w o r d s } \\
\text { Generation mean } \\
\text { analysis, Scaling } \\
\text { tests, Black gram, } \\
\text { Generations, Gene } \\
\text { actions }\end{array}$ & $\begin{array}{l}\text { NUK-15-02 } \times \text { GU- } 1 \text { of blackgram. The mean is partition in to additive, dominance and } \\
\text { epistatis by using six parameter model. Magnitude of dominance gene effect was higher } \\
\text { than the additive gene effect for most of traits in both the crosses. Among epistasis, } \\
\text { additive } \times \text { additive gene interaction was found to be significant in cross NUK-15-02 } \\
\text { NUK-15-07 for days to first flower, days to maturity, number of branches per plant, } \\
\text { number of seeds per plant, } 100 \text { seed weight and seed yield per plant and in cross NUK-15- } \\
02 \times \text { GU- } 1 \text { for days to first flower, days to maturity and } 100 \text {-seed weight. Dominance } \times\end{array}$ \\
\hline Article Info & $\begin{array}{l}\text { dominance component contributed significantly in cross NUK-15-02 } \times \text { NUK-15-07 for } \\
\text { branches per plant and } 100 \text { seed weight and in cross NUK-15-02 } \times \text { GU- } 1 \text { for davs to first }\end{array}$ \\
\hline $\begin{array}{l}\text { Accepted: } \\
\text { 15 August } 2020 \\
\text { Available Online: } \\
\text { 10 September } 2020\end{array}$ & $\begin{array}{l}\text { flower, days to maturity, plant height, branches per plant and } 100 \text { seed weight. Hence } \\
\text { selection should be carried out in later generation and it would be desirable to follow bi- } \\
\text { parental mating followed by population improvement approach that take care of both } \\
\text { additive and non-additive gene actions are more promising for the improvement of various } \\
\text { characters studied. }\end{array}$ \\
\hline
\end{tabular}

\section{Introduction}

Blackgram or urd (Vigna mungo (L.) Hepper) is one of the most highly prized pulses in tropical countries especially in India. The green pods are eaten as vegetable and they are highly nutritious. It has inevitably marked itself as the most popular pulse and can be most appropriately referred to as the "king of the pulses" due to its mouth watering taste and numerous other nutritional qualities.
Whether it be the very special "Dal makhni" of Punjab or the "Vada Sambhar" of South India, the taste rules the hearts of one and all alike. Indian immigrants have popularized the taste worldwide as well. An erect, suberect or trailing, densely hairy, annual herb. The tap root produces a branched root system with smooth, rounded nodules. The pods are narrow, cylindrical and up to six cm long. Urd is pulse crop of many Asian countries and it belongs to tribe phaseolus family fabaceae, it 
is an indigenous African annual legume, having high protein (20-25\%). Black gram's heat-loving nature makes them an ideal midsummer replenisher of soil organic matter and mineralizable nitrogen. For consumption purpose, it is largely used to make dal from the whole or split, dehusked seeds. The bean is boiled and eaten whole or, after splitting, made into dal; prepared like this it has an unusual mucilaginous texture. Available literature indicated that not much attempts have been made to obtain information on the presence of non-allelic gene interaction in the expression of yield and yield components in blackgram. The present work was therefore, undertaken to obtain more information on epistasis in addition to additive and dominance gene effects for grain yield and its component traits in blackgram by using generation means analysis.

\section{Materials and Methods}

The research experiment was carried out during summer-2020 at Pulses and Castor Research Station, Navsari Agricultural University, Navsari by taking six generation (P1, P2, F1, F2, BC1 and BC2) of each of the two crosses viz., NUK-15-02 $\times$ NUK-15-07 and NUK-15-02 $\times$ GU-1 in Compact Family Block Design with three replications. Observations were recorded on single plant basis for days to first flower, days to maturity, plant height, branches per plant, pods per plant, seeds per pod, pod length, 100 seed weight, seed yield per plant, harvest index and protein content. Mean values obtained from the observations recorded on representative plants and samples for quantitative characters for each entry in each family were used for statistical computation.

The scaling tests (A, B, C, and D) as described by Hayman and Mather (1955) were used to check the adequacy of the additive-dominance model for different characters in each cross, the significance of any one of these scales is taken to indicate the presence of non-allelic interaction. Various gene effects were estimated using six parameter model as suggested by Hayman (1958).

\section{Results and Discussion}

Predominant role of either additive or nonadditive gene actions have been reported in the inheritance of grain yield and its related traits in blackgram by number of workers. The information pertaining to gene action controlling various quantitative characters in any crop helps in selection of appropriate breeding procedure. To partition mean in to various genetic components a first order biometrical technique i.e. generation means analysis was adopted. The results of scaling test and gene action were depicted in table 1 and 2 .

\section{Days to first flower}

The scaling tests $\mathrm{A}$ and $\mathrm{D}$ were significant in cross NUK-15-02 $\times$ NUK-15-07 and A, C, and $\mathrm{D}$ in cross NUK-15-02 $\times$ GU-1. Dominance, additive $\times$ additive and dominance $x$ dominance effect were significant in the cross NUK-15-02 $\times$ NUK15-07. Additive, dominance and interaction component additive $\times$ additive and dominance $x$ dominance effect were significant in cross NUK-15-02 $\times$ GU-1. The result indicated that dominance and epistatic component additive $x$ additive and dominance $x$ dominance play major role in governance of this trait in cross NUK-15-02 $\times$ NUK-15-07. However in cross NUK-15-02 $\times$ GU-1, in addition to dominance and epistatic component, additive component also play important role. Simmilar results also reported by Vaithiyalingan et al., (2002), Srividhya et al., (2005) and Thamodharan et al., (2015). 


\section{Days to maturity}

The scaling test $\mathrm{B}, \mathrm{C}$ and $\mathrm{D}$ were found significant in cross NUK-15-02 $\times$ NUK-15-07 while, scaling test $\mathrm{A}, \mathrm{C}$ and $\mathrm{D}$ found significant in cross NUK-15-02 $\times$ GU-1. Estimation of genetic parameters indicated significance of dominance $(\mathrm{h})$ and additive $\times$ additive (I) type of interaction in cross NUK15-02 $\times$ NUK-15-07 and dominance (h), additive $\times$ additive (i) and dominance $\times$ dominance (1) were found significant in cross NUK-15-02 $\times$ GU-1. Based on result it is clear that both dominance and epistatis are importance in inheritance of days to maturity in both the crosses. This result is in accordance with the finding of Bhagirath et al., (2013), Karande et al., (2013) and Durga Prasad and Murugan (2015).

\section{Plant height (cm)}

In cross NUK-15-02 $\times$ NUK-15-07 out of four none of the scale observed significant, it indicated no mean difference was present between generations for this trait. Scaling test $\mathrm{A}$ and $\mathrm{C}$ were found highly significant in cross NUK-15-02 $\times$ GU-1 which indicated the presence of epistasis. Additive (d) and dominance $\times$ dominance (1) was found highly significant indicated role of additive and epistatic gene action in governance of this trait in this cross. Similar result were also found by Rehman et al., (2009, Haque et al., (2013) and Kachave et al., (2015).

\section{Branches per plant}

Significance of $\mathrm{C}$ and D scaling tests in cross NUK-15-02 $\times$ NUK-15-07 and B and C in cross NUK-15-02 $\times$ GU-1 revealed presence of non-allelic gene effects. The other parameters like dominance $(h)$, additive $\times$ additive (i) and dominance $\times$ dominance (l) were also found highly significant indicated presence of dominance and epistatis in expression of this trait in cross NUK-15-02 $\times$ NUK-15-07. Additive (i) and dominance $\times$ dominance (1) found significant in cross NUK-15-02 $\times$ GU-1 indicated role of additive and epistatis in inheritance of this trait in cross in this cross. This result is in accordance with the finding of Vaithiyalingan et al., (2002), Srividhya et al., (2005), Bhagirath et al., (2013) and Haque et al., (2013).

\section{Seeds per pod}

Non-allelic interaction was responsible as the scaling test $C$ had significant value in cross NUK-15-02 × NUK-15-07. However, cross NUK-15-02 $\times$ GU-1 simple additivedominance model were adequate. Genetic parameters viz., additive (d), dominance (h) and additive $\times$ additive (i) had highly significant values in cross NUK-15-02 $\times$ NUK-15-07 indicated role of additive, dominance and additive type of epistasis in inheritance of this trait. While alone additive component play major role in governance of this trait in cross NUK-15-02 × GU-1. Similar result were also found by Bhagirath et al., (2013) and Khattak et al., (2004).

\section{0 seed weight $(g)$}

The significance of scaling test $\mathrm{A}, \mathrm{B}$, and $\mathrm{D}$ in cross NUK-15-02 $\times$ NUK-15-07 and scaling test D in cross NUK-15-02 $\times$ GU-1 indicated in- adequacy of additive-dominance model. In both the crosses estimate of genetic components like additive (d), dominance (h), additive $x$ additive (i) and dominance $\times$ dominance (l) by six parameter model were found significant.

The result showed that all the genetic component except additive $\times$ dominance play major role in inheritance of this trait in both the crosses. The similar results were also found by Rehman et al., (2009), and Bhagirath et al., (2013). 
Table.1 Estimates of scaling test and gene effects for various characters in blackgram of cross NUK-15-02 $\times$ NUK-15-07

\begin{tabular}{|c|c|c|c|c|c|c|c|c|c|c|c|}
\hline \multirow[t]{2}{*}{ Characters } & \multicolumn{4}{|c|}{ Scale } & \multicolumn{6}{|c|}{ Parameters } & \multirow{2}{*}{$\begin{array}{c}\chi^{2} \text { Joint } \\
\text { scaling test }\end{array}$} \\
\hline & $\mathbf{A}$ & B & C & D & m & d & $\mathbf{h}$ & $\mathbf{i}$ & $\mathbf{j}$ & 1 & \\
\hline $\begin{array}{l}\text { Days to first } \\
\text { flower }\end{array}$ & $-3.60 * * \pm 1.30$ & $-1.47 \pm 1.24$ & $3.20 \pm 2.11$ & $4.13 * * \pm 1.00$ & $64.78 * * \pm 0.37$ & $-0.16 \pm 0.67$ & $-13.30 * * \pm 2.14$ & $-8.26^{* *} \pm 2.01$ & $-1.06 \pm 0.78$ & $13.33 * * \pm 3.43$ & $22.35 * *$ \\
\hline $\begin{array}{l}\text { Days to } \\
\text { maturity }\end{array}$ & $1.80 \pm 1.10$ & $2.46^{*} \pm 1.03$ & $7.66^{* * \pm 1.82}$ & $1.70 * \pm 0.79$ & $83.05^{* *} \pm 0.30$ & $0.26 \pm 0.51$ & $-6.73 * * \pm 1.73$ & $-3.40 * \pm 1.59$ & $-0.33 \pm 0.64$ & $-0.86 \pm 2.75$ & $19.63 * *$ \\
\hline Plant height & - & - & - & - & - & - & - & - & - & - & - \\
\hline $\begin{array}{l}\text { Branches per } \\
\text { plant }\end{array}$ & $0.46 \pm 0.59$ & $-0.13 \pm 0.69$ & $-3.26 * * \pm 1.12$ & $-1.80 * * \pm 0.54$ & $5.71 * * \pm 0.21$ & $-0.56 \pm 0.33$ & $5.33 * * \pm 1.14$ & $2.06^{* * \pm 1.08}$ & $2.06 \pm 0.41$ & $2.06 * \pm 1.73$ & $13.06 * *$ \\
\hline Seeds per pod & $-0.13 \pm 0.37$ & $-0.33 \pm 0.37$ & $-1.80 * * \pm 0.67$ & $-0.66 \pm 0.31$ & $6.63 * * \pm 0.12$ & $0.60 * * \pm 0.19$ & $1.83 * * \pm 0.67$ & $1.33 * \pm 0.63$ & $0.10 \pm 0.22$ & $-0.86 \pm 1.02$ & $10.80 *$ \\
\hline $\begin{array}{l}100 \text { seed } \\
\text { weight }\end{array}$ & $0.49 \pm 0.24$ & $0.86^{* *} \pm 0.27$ & $0.53 \pm 0.47$ & $-0.41 \pm 0.19$ & $3.78 * * \pm 0.08$ & $\begin{array}{c}- \\
0.58 * * \pm 0.11\end{array}$ & $0.98 * \pm 0.66$ & $0.82 * \pm 0.39$ & $-0.18 \pm 0.15$ & $-2.17 * * \pm 0.44$ & $14.40 * *$ \\
\hline $\begin{array}{l}\text { Seed yield per } \\
\text { plant }\end{array}$ & - & - & - & - & - & - & - & - & - & - & - \\
\hline Harvest index & $2.62 \pm 6.30$ & $-0.48 \pm 6.61$ & $-0.98 \pm 10.14$ & $-1.56 \pm 4.15$ & - & - & - & - & - & - & 0.47 \\
\hline
\end{tabular}

Table.2 Estimates of scaling test and gene effects for various characters in blackgram of cross NUK-15-02 × GU-1

\begin{tabular}{|c|c|c|c|c|c|c|c|c|c|c|c|}
\hline \multirow[t]{2}{*}{ Characters } & \multicolumn{4}{|c|}{ Scale } & \multicolumn{6}{|c|}{ Parameters } & \multirow{2}{*}{$\begin{array}{c}\chi^{2} \text { Joint } \\
\text { scaling } \\
\text { test }\end{array}$} \\
\hline & $\mathbf{A}$ & B & $\mathbf{C}$ & D & $\mathbf{m}$ & d & $\mathbf{h}$ & $\mathbf{i}$ & $\mathbf{j}$ & 1 & \\
\hline $\begin{array}{l}\text { Days to first } \\
\text { flower }\end{array}$ & $-4.20 * * \pm 1.44$ & $2.20 \pm 1.33$ & $12.06 * * \pm 2.38$ & $7.03 * * \pm 0.94$ & $64.11 * * \pm 0.36$ & $-17.46^{* * \pm 2.11}$ & $76.86^{* *} \pm 1.97$ & $-14.06^{* * \pm 1.88}$ & $-3.20 \pm 0.82$ & $16.06 * * \pm 3.38$ & $72.90 * *$ \\
\hline $\begin{array}{l}\text { Days to } \\
\text { maturity }\end{array}$ & $-3.73 * \pm 1.49$ & $-0.33 \pm 1.46$ & $8.00 * * \pm 2.10$ & $6.03 * * \pm 0.91$ & $81.58 * * \pm 0.26$ & $-0.66 \pm 0.75$ & $-17.10 * * \pm 2.05$ & $-12.06^{* * \pm 1.83}$ & $-1.70 \pm 0.89$ & $16.13 * * \pm 3.67$ & $54.70 * *$ \\
\hline Plant height & $-0.60 \pm 1.95$ & $-16.46^{* *} \pm 1.86$ & $-16.86 * * \pm 3.16$ & $0.10 \pm 1.17$ & $23.26 * * \pm 0.43$ & $3.10 * * \pm 0.78$ & $-3.30 \pm 2.69$ & $-0.20 \pm 2.34$ & $7.93 \pm 1.13$ & $17.26 * * \pm 4.45$ & $83.90 * *$ \\
\hline $\begin{array}{l}\text { Branches per } \\
\text { plant }\end{array}$ & $-0.73 \pm 0.72$ & $-3.66 * * \pm 0.85$ & $-4.26 * * \pm 1.30$ & $0.06 \pm 0.49$ & $5.15 * * \pm 0.18$ & $0.83^{*} \pm 0.33$ & $0.23 \pm 1.12$ & $-0.13 \pm 0.99$ & $1.46 \pm 0.47$ & $4.53 * \pm 1.86$ & $21.47 * *$ \\
\hline Seeds per pod & $-0.46 \pm 0.61$ & $-0.40 \pm 0.52$ & $-2.13 * \pm 1.00$ & $-0.63 \pm 0.45$ & - & - & - & - & - & - & 5.33 \\
\hline 100 seed weight & $0.30 \pm 0.26$ & $0.04 \pm 0.26$ & $-0.74 \pm 0.46$ & $-0.54 * \pm 0.21$ & $3.72 * * \pm 0.08$ & $-0.34 * \pm 0.13$ & $1.32 * \pm 0.45$ & $1.09 * \pm 0.42$ & $0.13 \pm 0.15$ & $-1.44 * \pm 0.70$ & $9.59^{*}$ \\
\hline $\begin{array}{l}\text { Seed yield per } \\
\text { plant }\end{array}$ & $-0.34 \pm 0.70$ & $-0.95 \pm 0.75$ & $-2.60 * \pm 1.21$ & $-0.65 \pm 0.57$ & $4.87 * * \pm 0.20$ & $-0.07 \pm 0.39$ & $2.01 \pm 1.23$ & $1.30 \pm 1.14$ & $0.30 \pm 0.43$ & $-0.01 \pm 1.98$ & $0.49 *$ \\
\hline Harvest index & $3.00 \pm 5.70$ & $-9.07 \pm 5.55$ & $-10.78 \pm 10.10$ & $-2.35 \pm 4.03$ & - & - & - & - & - & - & 6.73 \\
\hline
\end{tabular}




\section{Seed yield per plant}

In cross NUK-15-02 $\times$ NUK-15-07 nonsignificant mean square indicated no mean difference was present between generations for this trait. However, scaling test $\mathrm{C}$ registered significant value in NUK-15-02 $\times$ GU-1. The result of six parameter model indicated that only Additive (d) component was found significant indicated role of this component in governance of this trait in cross NUK-15-02 × GU-1. Similar result was found by Singh and Dikshit (2003) and Haque et al., (2013).

\section{Harvest index}

Non-significance estimates of all the four simple scaling test as well as $\chi^{2}$ value showed absence of epistasis for harvest index. The additive-dominance model was found adequate for both the crosses NUK-15-02 $\times$ NUK-15-07 and NUK-15-02 × GU-1.

In conclusion the simple additive-dominance model was appropriate in cross NUK-15-02 $\times$ NUK-15-07 for plant height, seed yield per plant and harvest index. Hence, selection in early generation itself improves mean performance in the progenies for these traits. Additive gene effects were found significant for seeds per pod and 100 seed weight and additive $\times$ additive (i) type epistatis found significant for days to first flower, days to maturity, branches per plant, seeds per pod and 100 seed weight. Such traits are improved by selection in later generation.

Traits like days to first flower, days to maturity, branches per plant, seeds per pod and 100 seed weight were govern by dominance and dominance $\times$ dominance type of gene action For the exploitation of dominance effect non-conventional breeding procedure might be adopted.
In case of cross NUK-15-02 $\times$ GU-1 for traits viz., seeds per pod and harvest index additivedominance model found adequate. Additive gene effect observed significant for days to first flowering, plant height, number of branches per plant and 100 seed weight indicated simple selection effectively improve these traits in at early stage of breeding program. Additive $\times$ additive (i) gene interaction were found to be significant in this cross for days first flower, days to maturity and 100 seed weight. The additive component of variation can be exploited by simple pedigree selection. Dominance $\times$ dominance gene interaction were found to be significant in this cross for days first flower, days to maturity, plant height, branches per plant and 100 seed weight while, additive $\times$ dominance (j) gene interaction was significant for plant height and branches per plant. For the exploitation of dominance effect nonconventional breeding procedure might be adopted, but due to "Papilionaceous flower" structure and absence of male sterility in blackgram exploitation of heterosis is not possible so, in that case pedigree method of breeding found rewarding to isolate superior segregants in segregating generation.

\section{References}

Hayman, B. I. and Mather, K. (1955).The description of genic interactions in continuous variation. Biometrics, 11(1): 69-82.

Hayman, B. I. (1958). The separation of epistatic from additive and dominance variation in generation. Heredity, 12: 371-390.

Bhagirath, R., Tikka, S.B.S. and Acharya, S. (2013). Heterosis and combining ability in blackgram (Vigna mungo (L.) hepper) under different environments. Indian J. of Agric. Sci., 83(6):611-616.

Durga Prasad, A.V.S. and Murugan, E. (2015).Combining ability analysis for 
yield and its attributes in Black gram (Vigna mungo (L.) Hepper). Elect. J. Pl. Breed., 6(2): 417-423.

Haque, A. F. M. M., Samad, M. A., Sarker, N., Sarker, J. K., Azad, A.K. and Deb, A. C. (2013). Gene effects of some agronomic traits through single cross analysis in blackgram (Vigna mungo L. Hepper). International J. Biosci., 3(6): 220-225.

Kachave G.A., Parde N.S., Zate D.K. and Harer P.N. (2015) Analysis of combining ability in Blackgram (Vigna mungo L. Hepper) International Journal of Advanced Research (2015), Volume 3, Issue 3, 1139-1146

Karande S. P., Rewale, A. P. and Nilakh S. B. (2013). Combining ability analysis in black gram (Vinga mungo (L.) hepper) Bioinfolet 10(2): 685-688.

Khattak, G. S. S., Asharaf, M. and Khan, M. S. (2004) Assessment of genetic variation for yield and yield components in mungbean [Vigna radiata (L.) Wilczek] using generation mean analysis. Pak. J.
Bot., 36(3): 583-588.

Rehman, A. U., Ali, M. A., Atta, B. M., Saleem, M., Abbas, A. and Mallahi, A. R. (2009). Genetic studies of yield related traits in mungbean (Vigna radiata L. Wilczek). Australian J. Crop Sci., 3(6): 352-360.

Singh, B. B. and Dikshit, H. K. (2003). Combining ability studies for yield and architectural traits in mung bean (Vigna radiata (L.) Wilczek). Indian J. Genet., 63(4): 351-352

Srividhya, A., Sekhar, M. R., Reddy, G. L. K. and Reddy, K.S. (2005).Components of genetic variation in bi-parental progenies of blackgram [Vigna mungo (L.) Hepper].Legume Research. 28(4): 291293.

Vaithiyalingan, M., Chidambaram, S., Vivekanandan, P. and Vanniarajan, C. (2002).Combining ability studies in blackgram [Vigna mungo (L.) Hepper]. Crop Res. Hisar. 24(1): 81-85.

\section{How to cite this article:}

Vadodariya, G. D., D. A. Chauhan, R. K. Patel, K. G. Modha, Y. V. Naghera and Jadav, S. K. 2020. Generation Mean Analysis for Yield and its Components in Blackgram [Vigna mungo (L.) Hepper]. Int.J.Curr.Microbiol.App.Sci. 9(09): 1838-1843. doi: https://doi.org/10.20546/ijcmas.2020.909.231 